\title{
The Yanomami Indians in the INTERSALT Study
}

\author{
Jairo de Jesus Mancilha-Carvalho, Nelson Albuquerque de Souza e Silva
}

Rio de Janeiro, RJ - Brazil

Objective - To study the distribution and interrelationship among constitutional and biochemical variables with blood pressure $(B P)$ in an population of Yanomami indians. To compare these findings with those of other populations.

Methods - The Yanomami indians were part of the INTERSALT, a study comprising 10,079 males and females, aged from 20 to 59 years, belonging to 52 populations in 32 countries in Africa, the Americas, Asia, and Europe. Each of the 52 centers was required to accrue 200 individuals, 25 participants in each age group. The variables analyzed were as follows: age, sex, arterial BP, urinary sodium and potassium excretion (24-hour urine), body mass index, and alcohol ingestion.

Results - The findings in the Yanomami population were as follows: a very low urinary sodium excretion (0.9 mmol/24h); mean systolic and diastolic BP levels of 95.4 $\mathrm{mmHg}$ and $61.4 \mathrm{mmHg}$, respectively; no cases of hypertension or obesity; and they have no knowledge of alcoholic beverages. Their BP levels do not elevate with age. The urinary sodium excretion relates positively and the urinary potassium excretion relates negatively to systolic BP. This correlation was maintained even when controlled for age and body mass index.

Conclusion - A positive relation between salt intake and blood pressure was detected in the analysis of a set of diverse populations participating in the INTERSALT Study, including populations such as the Yanomami Indians. The qualitative observation of their lifestyle provided additional information.

Keywords: blood pressure, dietary salt, arterial hypertension, epidemiology, risk factors

Hospital Universitário Clementino Fraga Filho of the Universidade Federal do Rio de Janeiro (FM/UFRJ) - Conselho Nacional de Desenvolvimento Científico e Tecnológico $(\mathrm{CNPq}) / \mathrm{MCT}$ and Ministério da Saúde.

Mailing address: Nelson Albuquerque de Souza e Silva - Condomínio Vale de Itaipu, c/502 - 24340-140 - Niterói, RJ, Brazil - E-mail: nelson@nce.ufrj.br

English version by Stela Maris C. e Gandour
The INTERSALT Study is an international cooperative epidemiological study carried out under the patronage of the Epidemiology and Prevention Council of the International Federation and Society of Cardiology (IFSC), which tries to clarify the relation between sodium $\left(\mathrm{Na}^{+}\right)$and potassium $\left(\mathrm{K}^{+}\right)$intake and blood pressure, and also the relation between blood pressure and other variables, such as weight, body mass index, and alcohol ingestion. It was designed to explore the intra- and interpopulation relations of the variables, ie, the relations of the variables and blood pressure within each population and the comparison between the different populations studied.

This study aimed at analyzing the relation between different constitutional, dietary and environmental variables and blood pressure among the Yanomami Indians, whom we studied, and to compare our findings with those reported in the INTERSALT Study, and also with other samples studied by other researchers.

\section{Methods}

In the INTERSALT Study, 10,079 males and females aged from 20 to 59 years representing 52 different populations in 32 countries in Africa, South and North America, Asia, and Europe were studied.

Each of the 52 centers was asked to accrue 200 males and females ranging in age from 25 to 59 years, with 25 participants in each age group. Except for some isolated populations, the participants were randomly selected. All investigators received the INTERSALT manual of operations and were trained and evaluated in the study methodology and protocol, which were exactly the same for the 52 centers ${ }^{1-5}$.

Blood pressure was measured twice as follows: with the patient in the sitting position with the random-zero sphygmomanometer, after emptying the urinary bladder; and after a 5-minute rest in the sitting position. The systolic blood pressure was measured in the first Korotkoff phase (appearance of the auscultatory sounds), and the diastolic blood pressure in the fifth phase (disappearance of the auscultatory sounds). The readings were performed at 2-mm Hg intervals. Casual and 24-hour urine samples were 
collected from all participants for electrolyte measurements. The aliquots of urine were frozen and sent to the INTERSALT central laboratory at the University of St. Raphael in Louvain, Belgium, where the analyses were performed with strict quality control. Urine collection and blood pressure measurement were repeated in a random $8 \%$ sample of the participants to estimate the intraindividual variability. All data were sent to the Coordination Center in London for review and analysis.

Weight and height were measured twice with a stadiometer and a standardized scale. Sodium and potassium were measured with the flare photometer. Alcohol ingestion was assessed in each participant.

The blood pressure level used in the analysis was the mean of the 2 measurements recorded. Urinary sodium and potassium excretion was the product of the concentrations in urine and the 24-hour urinary volume. Body mass index was calculated dividing the weight in kilograms by the square of the height $\left(\mathrm{kg} / \mathrm{m}^{2}\right)$.

The median of the variables was analyzed and multiple linear regression was applied to study the relation between the variables.

\section{Results}

To investigate the relation between the 24-hour urinary sodium excretion and blood pressure in the participants, multiple linear regression was used with control for age, sex, weight, potassium excretion, and alcohol ingestion. The coefficients of these analyses (blood pressure difference in $\mathrm{mm} \mathrm{Hg}$ for each unit of sodium difference) were separately computed for each of the 52 centers.

In 39 of the centers studied, the coefficients were positive with control for sex and age, and, in 33 centers, the coefficients were positive with control for body mass index, potassium excretion, and alcohol ingestion. Of these 33 centers, the coefficients were statistically significant in 8 .

When the 52 centers were combined, a highly significant statistical relation was observed between sodium excretion and systolic blood pressure for the 10,079 partici-

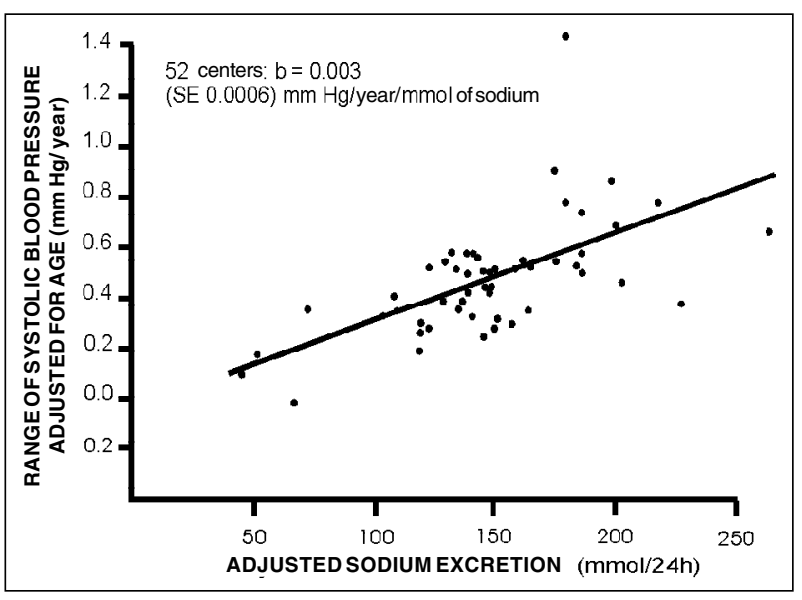

Fig. 1 - Systolic blood pressure and urinary sodium excretion. pants (fig. 1). The higher the urinary sodium excretion (and, therefore, the sodium intake), the higher the blood pressure.

This relation exists in males and females and is more drastic in older participants. This significant relation between sodium and systolic blood pressure persisted when the hypertensive individuals were excluded from the analysis. This positive relation between sodium and systolic blood pressure in the individuals was observed in all ranges of blood pressure levels, it was not only restricted to the minority of "salt-sensitive" individuals (those in the highest range of blood pressure distribution).

The relation between urinary sodium excretion and diastolic blood pressure was also positive, but weaker than that between urinary sodium excretion and systolic blood pressure.

Potassium excretion was statistically significant and inversely related to systolic and diastolic blood pressure in the individuals studied, even when controlled for sex, age, body mass index, sodium intake, and alcohol ingestion.

A strong association between $\mathrm{Na}^{+} / \mathrm{K}^{+}$excretion ratio and systolic and diastolic blood pressure was observed in the individuals studied.

The INTERSALT Study found a strong, positive, and significant relation between body weight (body mass index) and systolic and diastolic blood pressure. A strong association was observed between great alcohol ingestion (more than $300 \mathrm{~mL}$ of alcohol per week) and systolic and diastolic blood pressure.

The data analysis of 4 isolated populations (Yanomami Indians, Indians from Xingu, rural population of Kenya, and rural population of Papua, New Guinea) showed that neither blood pressure elevation with age is inevitable, nor is the high prevalence of hypertension. With a urinary sodium excretion ranging from $0.9 \mathrm{mmol} / \mathrm{day}$ to $51 \mathrm{mmol} / \mathrm{day}$ (compared with the mean of $165 \mathrm{mmol} / \mathrm{day}$ in the other 48 centers), blood pressure means were clearly lower in those 4 centers than in the remaining 48 , blood pressure elevation with age was minimum or even negative, and hypertension virtually did not exist (tab. I).

Even in these centers of low $\mathrm{Na}^{+}$intake, a positive relation between $\mathrm{Na}^{+}$intake and blood pressure exists (fig. 2).

The interpopulation analyses had greater methodological problems than the intrapopulation ones with a large sample and standardized methods, because the populations differ from each other in many ways other than the variables that could be analyzed in the INTERSALT Study. Despite this, a positive and significant association was found between systolic blood pressure and $\mathrm{Na}^{+}$excretion in the 52 centers. When the 4 centers with low $\mathrm{Na}^{+}$intake were excluded, the association continued to be positive, but not significant.

The analysis of the curve of blood pressure elevation with age showed a strong and significant association with $\mathrm{Na}^{+}$excretion (fig. 1). The greater the $\mathrm{Na}^{+}$intake, the greater the elevation in blood pressure with age found in the analysis of the 52 centers, and also when the 4 centers with low $\mathrm{Na}^{+}$intake were not included. 


\begin{tabular}{|c|c|c|c|c|c|}
\hline Variables & Yanomami & Xingu & $\begin{array}{c}\text { Papua } \\
\text { New Guinea }\end{array}$ & Kenya & $\begin{array}{l}\text { The other } \\
48 \text { centers }\end{array}$ \\
\hline \multicolumn{6}{|l|}{ Factors related to lifestyle } \\
\hline 24-hour sodium (mmol-median) & $<1$ & 6 & 27 & 51 & 160 \\
\hline Sodium/potassium ratio (median) & $<0.01$ & 0.08 & 0.48 & 1.8 & 3.4 \\
\hline BMI & 21.2 & 23.4 & 21.7 & 20.8 & 25.2 \\
\hline Alcohol ingestion (\%) & 0 & 0 & 8.7 & 30.7 & 53.0 \\
\hline \multicolumn{6}{|l|}{ Blood pressure } \\
\hline Systolic BP (median) & 95.4 & 98.9 & 107.7 & 109.9 & 118.7 \\
\hline Diastolic BP (median) & 61.4 & 61.7 & 62.9 & 67.9 & 74.0 \\
\hline Hypertensive individuals $(\%)^{*}$ & 0 & 1.0 & 0.8 & 5.0 & 17.4 \\
\hline $\begin{array}{l}\text { Relation between systolic BP and age } \\
(\mathrm{mm} \mathrm{Hg} / 10 \text { years })\end{array}$ & -1.1 & +0.6 & -1.4 & +2.4 & +5.0 \\
\hline
\end{tabular}

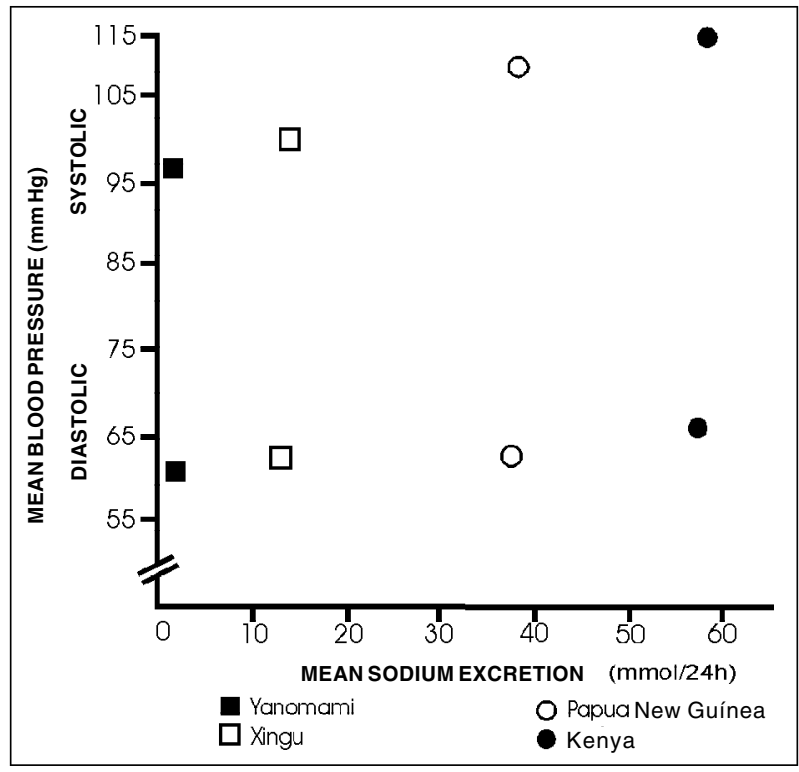

Fig. 2 - Blood pressure and urinary sodium excretion in 4 isolated populations.

The Yanomami group differed from the other groups studied in the INTERSALT Study due to their lower $\mathrm{Na}^{+}$ intake $(0.9 \mathrm{mmol} / 24 \mathrm{~h})$, lower blood pressure levels (mean systolic and diastolic blood pressure levels of 95.4 and $61.4 \mathrm{mmHg}$, respectively), no alcohol ingestion, absence of blood pressure elevation with age, and no hypertension (tab. I and fig. 3).

\section{Discussion}

The $\mathrm{Na}^{+}$excretion level of the Yanomami sample analyzed in the INTERSALT Study was the lowest in an adult population ever reported in the literature. Similar data were found in other samples of the Yanomami population ${ }^{6-8}$. The potassium excretion in the Yanomami sample was greater than that found in 35 of the 52 samples of the INTERSALT Study. Adults of industrialized populations have an increase in weight with age ${ }^{9,10}$. The Yanomami Indians did not increase their weight with age.
Several studies with isolated populations with low salt intake in different parts of the world have shown no increase in blood pressure with age ${ }^{11-24}$. A few studies have reported a decrease in blood pressure with age ${ }^{7,20}$. These populations are usually characterized by a $\mathrm{Na}^{+}$-poor and $\mathrm{K}^{+}$-rich diet.

The lack of blood pressure increase with age was suggested to be due to the presence of chronic diseases and malnutrition ${ }^{25,26}$. The authors observed no signs of malnutrition or protein deficiency in the participants of the Yanomami sample of the INTERSALT Study; on the contrary, the authors were impressed by the physical resistance of the Yanomami Indians, who are used to carrying a lot of weight through the forest for hours. Truswell et al ${ }^{20}$ and Page et $\mathrm{al}^{21}$ have also reported a good nutritional status in the isolated populations in Africa and in the Solomon Islands, where no increase in blood pressure with age was found.

The Yanomami Indians are evidence that an active lifestyle with little salt intake is possible. Oliver et al ${ }^{6}$ have reported similar levels of $\mathrm{Na}^{+}$excretion in Yanomami groups in Venezuela and have associated them with elevated plasma levels of renin and aldosterone. These hormonal adaptations to a very low $\mathrm{Na}^{+}$intake may play an important role in maintaining and reabsorbing the $\mathrm{Na}^{+}$filtered by the kidneys, and may reflect the human capacity to adapt to a

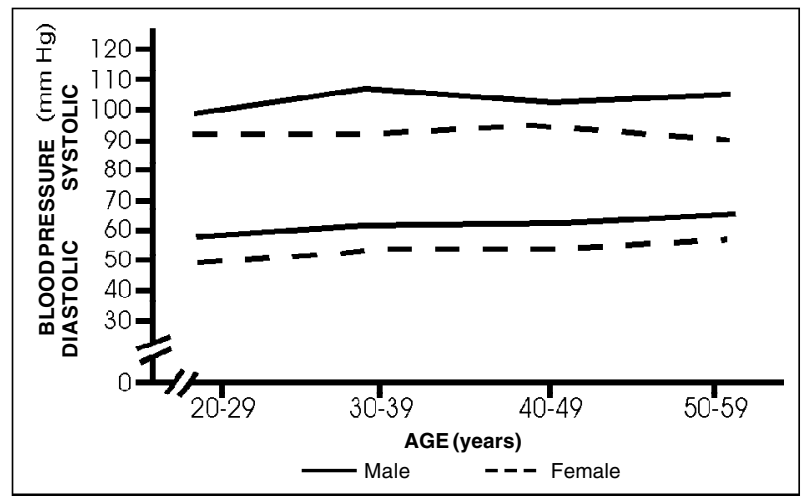

Fig. 3 - Blood pressure and age (Yanomami Indians). 


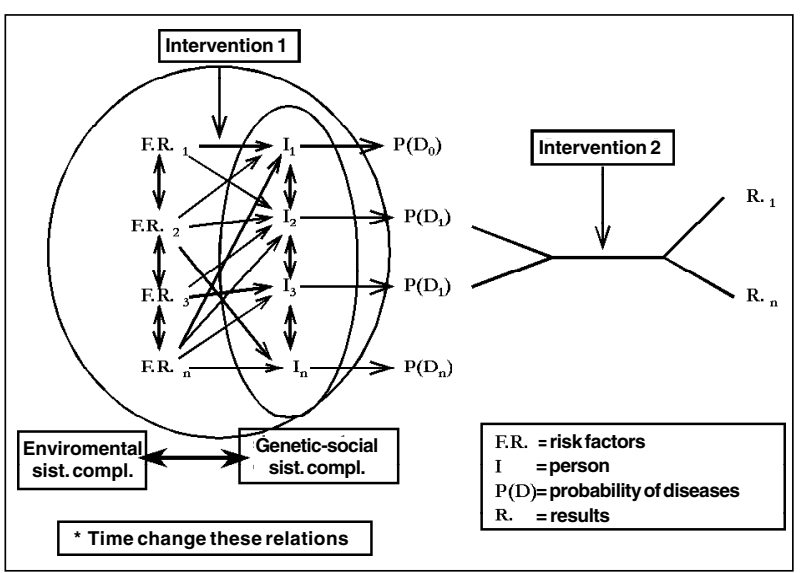

Fig. 4-Causal model of diseases.

sodium-salt-deficient diet, an adaptation originated in the predominantly vegetarian diet of human primate ancestors ${ }^{27}$. This type of diet prevailed for thousands of years of human evolution, from nomadic food gatherer to hunter, before the development of agriculture and animal domestication and breeding 27,28 .

Because the blood pressure control system is redundant, ie, several systems control blood pressure in addition to the renin-angiotensin-aldosterone system, the excessive stimulation of this system by low salt intake is not able to elevate blood pressure. This may be due to other physiological mechanisms, such as vasodilators, that may compensate the stimulation of this vasoconstrictor and salt-preserving system. In a redundant system, alteration in one of its components affects or interferes with the others, causing the entire system to readjust, either by maintaining the result (in this case, unaltered blood pressure level), or readjusting the system in a new plateau. Another example of stimulus of the renin-angiotensin-aldosterone system is renal artery stenosis. One clinical-pathologic study has long shown that renal artery stenosis does not necessarily elevate blood pressure ${ }^{29}$. In that study, $17 \%$ of the normotensive patients had renal artery stenosis greater than 50\%. On the other hand, the classic concept that activation of the renin-angiotensin-aldosterone system is the only cause of the development and maintenance of renovascular hypertension has been reviewed. Experimental evidence indicates that other systems, such as the lipoxygenase pathway, seem to play a more critical role in maintaining high blood pressure after renal artery stenosis ${ }^{30}$.

In addition to low $\mathrm{Na}^{+}$intake and high $\mathrm{K}^{+}$intake, other factors that may contribute to the absence of hypertension and lack of blood pressure increase with age among the Yanomami Indians are as follows: their low body mass index and the almost nonexistence of obesity, no alcohol ingestion, low ingestion of saturated fat, high ingestion of fibers, relatively high physical activity, and the several cultural consequences of living in an isolated community without the psychosocial stress of civilization and without a monetary system or dependence on a job.
One of the coordinators of the INTERSALT Study, Dr. Jeremiah Stamler, discussing the implications of the study ${ }^{3,31,32}$, stated that based on the findings, one may estimate that with a reduction in mean $\mathrm{Na}^{+}$intake to $100 \mathrm{mmol} /$ day (a teaspoon of salt), a reduction in mean body mass index to $22 \mathrm{~kg} / \mathrm{m}^{2}$, an increase in $\mathrm{K}^{+}$intake to increase the $\mathrm{Na}^{+} / \mathrm{K}^{+}$ratio to 1 , and with elimination of excessive alcohol ingestion, the mean systolic blood pressure would be $6 \mathrm{mmHg}$ lower. A clinician may observe that, in an individual patient, blood pressure may vary more than that in minutes. But a difference of $6 \mathrm{mmHg}$ has another meaning when applied to a population. Estimated from other epidemiological studies (Framingham, Western Electric, MRFIT), a 6-mm Hg reduction in systolic blood pressure would reduce mortality due to coronary artery disease by $10 \%$ and mortality due to stroke by $16 \%$.

The study of the Yanomami Indians, which we started in 1982, was originally presented as a thesis of the Postgraduation Program in Cardiology of the Medical School of the Universidade Federal do Rio de Janeiro by one of the authors ${ }^{7}$ and oriented by the other author of the present study. This study contributed to the understanding of the complex man/environment interaction in determining diseases, and, in this case, the risk factors for cardiovascular diseases. This isolated population, was only contacted by the so-called "civilized" world in the mid 20th century. Arterial hypertension does not exist among the Yanomami Indians, while $38 \%$ of the urban population of Rio de Janeiro ${ }^{33}$, which was also examined, has blood pressure levels above 140/90 $\mathrm{mmHg}$ or uses antihypertensive drugs. The Yanomami Indians are not obese, their blood pressure does not increase with age, their mean total serum cholesterol levels are $122 \mathrm{mg} \%$ for males and $142 \mathrm{mg} \%$ for females and their LDL-cholesterol levels are $68 \mathrm{mg} \%$ for males and $78 \mathrm{mg} \%$ for females, which are almost half those levels reported in the Brazilian populations of large cities or of other countries ${ }^{34-36}$. In addition, the low salt intake in this population was fundamental for confirming in the INTERSALT Study the positive relation between salt intake and blood pressure levels, an old doubt in the pathophysiology of blood pressure elevation. The findings in the Yanomami Indians indicate that the high prevalence of cardiovascular risk factors among us, mainly in populations at the lower socioeconomic level, are significantly associated with life conditions, and, therefore, may be controlled independently of what may be discovered about the genetic basis of these cardiovascular risk factors.

The complex relation among individuals (an interrelated set of genes), society (interrelated set of individuals), and environment (ecosystem in which the individual is inserted) in determining diseases needs to be understood within new paradigms of thought, such as that of complex systems ${ }^{37,38}$ and no longer within the deterministic or even multideterministic paradigm of cause and effect. This is necessary to a better understanding of the health-disease complex within a temporal evolution, ie, along the individual's history of life. The multivariate analysis used in this 
study is one of the quantitative statistical instruments used to understand this complex interaction. Other methods of observing and describing reality, both quantitative and qualitative, and trying to reproduce or predict what will happen based on an initial observation (mathematical predictive or statistic models or the neural webs or the Markov chains) should be added in the search for scientific truth.

Figure 4 proposes a simplified causal model. In this model, we see that a certain disease $\left(\mathrm{D}_{1}\right)$ has the probability $\left(\mathrm{PD}_{1}\right)$ to result from the combination of different variables or environmental risk factors $\left(\mathrm{FR}_{1}, \mathrm{FR}_{2}, \mathrm{FR}_{3}, \mathrm{FR}_{\mathrm{n}}\right.$ - complex environmental system - ecosystem) acting for varied periods of time upon 2 individuals $\left(\mathrm{I}_{2}\right.$ and $\left.\mathrm{I}_{3}\right)$, who live in a society $\left(I_{1+} I_{2+} I_{3+} I_{n}\right.$ - complex genetic-anthropo-social system) within that environmental system. On the other hand, the same environmental risk factors $\left(\mathrm{FR}_{1}-\mathrm{FR}_{\mathrm{n}}\right)$ combined may cause absence of disease or different diseases $\left(\mathrm{D}_{0}\right.$, $\left.D_{n}\right)$ in different individuals $\left(I_{1}, I_{n}\right)$. This complex interaction is still dependent on the time factor $(t)$, both the initial moment of action within the evolution of the system (initial stage) and the duration period of action. It is worth noting that each individual may be exposed to the environmental factor in different moments of his/her evolutionary history and for different periods of time, and that this individual, to control a physiological variable such as blood pressure, relies on redundant systems, which are under the control of several genes and may affect the outcome. Small changes in the initial stage may cause great changes in the system at another moment in time ${ }^{39}$. It is worth noting that the risk factors may be facilitatory or inhibitory, ie, they may act positively or negatively upon the system in regard to a certain outcome and in a certain individual, depending on the organization of the system (as environmental, genetic, and social variables interact).

Because one disease may be the result of different combinations in different individuals and in different societies, the results $(\mathrm{R} 1, \mathrm{Rn})$ of one same treatment may be different. Therefore, it is not a surprise to verify that antihypertensive drugs reduce the relative risk of cardiovascular events in less than $45 \%$. To understand these complex relations in an individual and to know how to choose or judge the best treatment for each patient is fundamental in clinical practice.

The study of the Yanomami Indians, even without knowing the human genome, as it shows the absence of some known coronary risk factors in a population that is organized in a society and lives in a completely different ecosystem from ours (inhabitants of large cities), shows that blood pressure in that environment-society does not necessarily increase with age or even with the excessive stimulation of the renin-angiotensin-aldosterone system. This enables proving that a clear relation between salt intake and blood pressure exists and points to the need for a change in the paradigm from a deterministic or multideterministic thought to a complex thought ${ }^{40}$, so the causal relations in medicine will be better understood.

\section{References}

1. The INTERSALT Cooperative Research Group. INTERSALT: An international study of electrolyte excretion and blood pressure: results for 24-hour urinary sodium and potassium excretion. Br Med J 1988; 297: 319-28.

2. Eliot P, Stamler R. Manual of operations for "INTERSALT", an international cooperative study on the relation of sodium and potassium and blood pressure. Controlled Clin Trials 1988; 9(suppl): 1-118.

3. Stamler R, Stamler J. The INTERSALT Study: design and methods, results and implications for public health and medical care. Heartbeat 1994; 1: 3-4.

4. Mancilha-Carvalho JJ, Baruzzi RG, Howard PF, et al. Blood pressure in four remote populations in the INTERSALT study. Hypertension 1989; 14: 238-46.

5. Mancilha-Carvalho JJ, Oliveira R, Espósito RJ. Blood pressure and electrolyte excretion in the Yanomamo Indians, an isolated population. J Human Hypertension 1989; 3: 309-15.

6. Oliver WJ, Cohen EL, Neel JV. Blood pressure, sodium intake and sodium-related hormones in the Yanomamo Indians, a "no salt" culture. Circulation 1975; 52: 146-51.

7. Mancilha-Carvalho JJ. Estudo da pressão arterial de índios Yanomami (Tese de Doutorado). Rio de Janeiro: Universidade Federal do Rio de Janeiro, 1985.

8. Mancilha-Carvalho JJ, Souza e Silva NA, Carvalho JV, Lima JAC. Pressão arterial em seis aldeias Yanomami. Arq Bras Cardiol 1991; 56: 477-82.

9. Chiang BP, Perlman LV, Epstein FH. Overweight and hypertension: a review. Circulation 1969; 39: 403-21.

10. Berchtold P. Clinical and epidemiologic evidence relating caloric intake, obesity and hypertension. In: Horan MJ, Blaustein M, Dunbar JB, Kachadorian W, Kaplan MA, Simpouplos AP, eds. NIH Workshop on Nutrition and Hypertension. New York: Biochemical Information Corporation, 1984: 189.

11. Froment A, Milon H, Gravier CH. Relation entre consommation sodée et hypertension artérielle, contribution de l'épidemiologie géographique. Rev Epidem Santé Publ 1979; 27: 437-54.
12. Gleiberman L. Blood pressure and dietary salt in human populations. Ecology of Food and Nutr 1973; 2 : 143-56.

13. Lowenstein FW. Blood pressure in relation to age in the tropics and subtropics: a review of literature and an investigation in two tribes of Brazil Indians. Lancet 1961; 1: 389-92.

14. Cerqueira MT, Fry MM, Connor WE. The food and nutrition intake of Tarahumara indians of Mexico. Am J Clin Nutr 1979; 2: 905-15.

15. Page LB. Epidemiologic evidence on the etiology of human hypertension and its possible prevention. Am Heart J 1976; 91: 527-34.

16. Labarthe D, Reed D, Stallones R. Health effects of modernization in Palau. Am J Epidemiol 1973; 98: 161-74.

17. Cruz-Coke R, Etchevery R, Nagel R. Influence of migration on blood pressure of Easter Islanders. Lancet 1964; 1: 697-9.

18. Friedlaender JS, et al. The Solomon Islands Project - A Long Term Study of Health, Human Biology, and Culture Change. Oxford: Clarendon Press, 1987: 1.

19. Sinnet PF, Shyte HM. Epidemiological studies in a total highland population, Tukisenta New Guinea: cardiovascular disease and relevant clinical, electrocardiographic, radiological and biochemical findings. J Chronic Dis 1973; 26: 265-90.

20. Truswell AS, Kennely BM, Hansen JDL, Lee RB. Blood pressure of Kung bushman in northern Botswana. Am Heart J 1972; 84: 5-12.

21. Page LB, Damon A, Moellering Jr RJ. Antecedents of cardiovascular disease in six Solomon Island societies. Circulation, 1974; 49: 1132-46.

22. Maddocks I. Blood pressure in Melanesians. Med J Aust, 1967; 1: 1123-6.

23. Prior IAM, Grimley-Evans J, Harvey HPB, Davidson F, Lyndsey M. Sodium intake and blood pressure in two Polynesian populations. N Engl J Med 1968; 279: 515-20.

24. James GD, Baker PT. Human population biology and hypertension: evolutionary and ecological aspects of blood pressure. In: Laragh JH, Brenner BM, eds. Hypertension: Pathophysiology, Diagnosis, and Management. New York: Raven Press, 1990: 137. 
25. Burns-Cox CJ, Maclean JD. Splenomegaly and blood pressure in an Orang Asli Community in West Malaysia. Am Heart J 1970; 80: 718-9.

26. Maddocks I, Vine AP. The influence of chronic infection on blood pressure in New Guinea males. Lancet 1966; 2: 262-4.

27. Leakey RE, Lewin R. Origins. New York: Dutton FP, 1977.

28. Denton D. The hunger for salt: An anthropological, physiological and medical analysis. Berlin/Heidelberg/New York: Springer-Verlag, 1982.

29. Holley KE, Hunt JC, Brown AL Jr, Kincaid OW, Sheps SG. Renal artery stenosis: a clinical-pathologic study in normotensive and hypertensive patients. Am J Med 1964; 37: 14-22.

30. Romero JC, Feldstein AE, Rodriguez-Porcel MG, Cases-Amenos A. New insights into the pathophysiology of renovascular hypertension. Mayo Clin Proc 1997; 72: 251-60.

31. Stamler J. Blood pressure and high blood pressure: aspects of risk. Hypertension 1991; 18(suppl I): 95-107.

32. Stamler J. Dietary salt and blood pressure. Annals of the New York Academy of Sciences 1993; 676: 122-56.
33. Klein CH, Souza e Silva NA, Nogueira AR, Bloch KV, Campos LHS. Hipertensão arterial na Ilha do Governador, Rio de Janeiro, Brasil. II. Prevalência. Cadernos de Saúde Pública (Reports in Public Health) 1995; 11: 389-94.

34. Mancilha-Carvalho JJ, Crews DE. Lipd profiles os Yanomamo indians of Brazil. Preventive Medicine 1990; 19: 66-75.

35. Mancilha-Carvalho JJ, Carvalho JV, Lima JAC, Souza e Silva NA. Ausência de fatores de risco de doença coronariana em índios Yanomami e influência da aculturação na pressão arterial. Arq Bras Cardiol 1992; 59: 275-83.

36. Carneiro O. Níveis de lípides sangüíneos em diferentes populações brasileiras. Arq Bras Cardiol 1979; 32: 361-5

37. Morin E. Towards a study of humankind. Volume 1: The Nature of Nature. New York: Peter Lang Publishing, Inc., 1992.

38. Morin E. La Methode. La Connaissance de la Connaissance. Vol. 3.: Editions du Seuil, 1986.

39. Lorenz EN. A Essência do Caos. Editora Universidade de Brasília, 1996: 278p.

40. Pena-Veja A, Nascimento EP. O pensar complexo. Edgar Morin e a Crise da Modernidade. 2a . ed. Rio de Janeiro: Editora Garamond Ltda, 1999: 204p. 